\title{
Heterosis Studies in Okra (Abelmoschus esculentus L. Moench)
}

\author{
M.I. Makdoomi ${ }^{1}$, Kouser P. Wani ${ }^{1}$, Z.A. Dar $^{2}$, K. Hussain ${ }^{1}$, Ambreen Nabi ${ }^{1 *}$, \\ Faheema Mushtaq ${ }^{1}$ and Shahnaz Mufti ${ }^{1}$
}

${ }^{1}$ Division of Vegetable Sciences, Sher-e-Kashmir University of Agricultural sciences and Technology-Kashmir Shalimar Srinagar 190025(J\&K), India

${ }^{2}$ Dry Land Agriculture Research Station, Budgam, Kashmir, India

*Corresponding author

\section{A B S T R A C T}

In the present experiment, a study was conducted during kharief 2012 at three locations. Also the crosses were evaluated at the farmer's field on the basis of questionnaire developed. The basic material consisted of ten diverse genotypes of Okra (Abelmoschus

Keywords

Abelmoschus esculentus L. (Moench), Heterosis, Okra, Pod yield, Participatory plant breeding

Article Info

Accepted: 26 January 2018 Available Online: 10 February 2018 esculentus L. (Moench) viz., SKBS-11, Pant Bhindi, IC-117018, Azad Ganga, Parbhani Kranti, Lam-1, GO-2, Red Bhindi, Aka Anamika and Pusa Sawani. The selected ten genotypes were crossed in all possible combinations and produced forty five crosses. The observations viz., days to first flowering, days to first pod picking, plant height, number of nodes, internodal length, pod length, pod girth, average pod weight, number of pods plant $^{-1,}$ pod yield plant ${ }^{-1}$, number of seeds $\operatorname{pod}^{-1}, 100$ seed weight, seed yield plant ${ }^{-1}$, and pod yield were recorded. The results revealed wide range of heterotic pattern for different traits. The heterosis over better parent ranged from -11.38 to $8.82 \%$ for days to first flowering, -12.80 to $5.53 \%$ for days to first pod picking, 20.28 to $-24.46 \%$ for plant $\mathrm{h}$ eight, 17.26 to $-7.26 \%$ for number of nodes, -29.62 to $-24.36 \%$ for internodal distance, 23.65 to- $33.32 \%$ for pod length, -30.24 to $3.22 \%$ for pod girth,33.69 to $-9.38 \%$ for average pod weight, 30.41 to $-4.78 \%$ for number of pods ${ }^{-1}, 57.13$ to $-0.43 \%$ for pod yield plant ${ }^{-1}$ and 55.00 to $-0.38 \%$ for pod yield $\mathrm{ha}^{-1}$. The superior crosses identified through heterosis analysis and through farmers' participatory mode of plant breeding were SKBS-11 x IC117018, SKBS-11 x Parbhani Kranti, IC-117018 X Pusa Sawani, Pant Bhindi x Pusa saqwani and Pant Bhindi x Azad Ganga.

\section{Introduction}

Okra is cultivated for its green, immature, non-fibrous fruits or pods containing round seeds. Okra is known as a multipurpose plant. Its immature fruits are used as vegetable, roots and stem for clarification of sugar cane juice to make gur, ripe seeds are roasted and used as a substitute for coffee in some countries, mature fruits and stems containing crude fibre are used in the paper industry.

Extracts from the seeds of okra is an alternative source for edible oils. The greenish yellow edible oil has a pleasant taste and odour and is high in unsaturated fats like oleic acid and linolic acid. The oil content of the seeds is quite high at about $40 \%$. 
Okra is a highly nutritious vegetable besides having medicinal importance. It is a potential source of numerous minerals like phosphorus, potassium, sulphur, calcium, iron, sodium etc and vitamins $\mathrm{A}, \mathrm{B}$ and $\mathrm{C}$. The amount of ascorbic acid content varies from 13-18 $\mathrm{mg} / 100 \mathrm{~g}$ of fresh fruit weight; while as green tender fruits and immature seeds have a little protein content 2.08 and $2.09 \%$ respectively (Singh et al., 2001). Fresh okra fruits contain both soluble and insoluble fibres. The soluble fibre is in the form of gums and pectins. It helps to lower serum cholesterol, reducing the risk of heart diseases. The insoluble fibre present in the fruits helps to keep the intestinal tract healthy, decreasing the risk of colon cancer and also helps to stabilize the blood sugar. It is also reported to be useful for persons suffering from genitor- urinary disorders In Jammu and Kashmir, it is mainly grown during the kharief season. The crop is grown but on small scale. Due to tourist influx and floating populations in the valley, the crop is gaining importance day by day. However susceptibility of suitable cultivars to diseases and pests necessitates development of superior varieties and hybrids superior in yield and quality, which needs creation of variability and identification of desirable segregants through hybridization. Moreover, the recent surge in widespread adoption of hybrids by farmers also necessitates the development of new and higher yielding hybrids which are able to realize the high degree of economic heterosis. In addition to cross pollinated species, the phenomenon of heterosis has also been commercially useful in self and often cross pollinated species, wherever it was technically feasible because of manifestation of heterosis for different traits. In the present study, the heterosis was computed over the better parent (heterobeltiosis) for each trait from the data pooled over environments. Keeping all the facts under consideration, present investigation, involving a diallel crossing programme on ten diverse lines of okra, was initiated to generate information on genetic parameters and for identification of superior cross combinations. The investigation was carried out with objective to study the nature and extent of heterosis for different traits in various cross combinations.

\section{Materials and Methods}

The experimental material was tested during Kharif 2012 at three locations viz., Vegetable Experimental Farm, SKUAST-Kashmir, Shalimar; Mountain Research Centre for Field Crops, Khudwani and Regional Research Station and Faculty of Agriculture, Wadura. Also, the crosses were evaluated at the farmer's field at Palpora, Srinagar on the basis of questionnaire developed. The basic materials consisted of ten diverse genotypes of okra viz. SKBS-11, Pant Bhindi, IC-117018, Azad Ganga, Parbhani Kranti, Lam-1, GO-2, Red Bhindi, Arka Anamika and Pusa Sawani. These lines/ varieties have been maintained by the Division of Vegetable Science, SKUAST$\mathrm{K}$, Shalimar and have been selected for the present study on the basis of genetic variability for various agronomic traits and maturity parameters. The genotypes represented wide genetic diversity. The selected ten genotypes were crossed in all possible combinations, without reciprocals and produced forty five crosses. The seeds obtained from the crossing block were sown during kharief 2013 to raise hybrid block. Cultural and agronomic practices were followed as per the standard recommendations and need based plant protection measures were taken to maintain healthy crop stand. The observations like days to first flowering, days to first pod picking, plant height $(\mathrm{cm})$, number of nodes, internodal length $(\mathrm{cm})$, pod length $(\mathrm{cm})$, pod girth $(\mathrm{cm})$, average pod weight $(\mathrm{g})$, number of pods plant $^{-1}$, pod yield plant ${ }^{-1}$ (g)'number of seeds pod ${ }^{-1}, 100$ seed weight, seed yield plant $^{-1}$ and pod yield ( $\mathrm{t} / \mathrm{ha}$ ) were recorded. The magnitude of heterosis was 
calculated as per the standard procedure and significance of heterosis was tested using the formula suggested by Wynne et.al. (1970).

\section{Results and Discussion}

In the present study, heterosis was estimated over better parent using only pooled data over the environments for the entire cross combinations and expressed as per cent (Table 1). The results revealed wide range of heterotic pattern for different traits. For days to first flowering negative heterosis over the better parent was exhibited by SKBS-11 $\mathrm{x}$ GO-2, SKBS-11 x Arka Anamika, SKBS-11x Lam-1, Parbhani Kranti x Red Bhindi and Azad Ganga x Lam-1, with heterosis ranging from-11.38 to8.82\%. Days to first pod picking exhibited significant negative heterosis over the better parent in cross combinations IC117018 x Arka Anamika, SKBS-11x Arka Anamika, Pant Bhindi x Go-2, Red Bhindi x Arka Anamika and Parbhani Kranti xRed Bhindi with a heterotic range of -12.80 to 5.535. For plant height the cross combinations showing desirable positive heterosis over the better parent were SKBS-11 x Pusa Sawani, SKBS-11 x Arka Anamika, GO-2 xArka Anamika, Prabahni Kranti x Arka Anamika and SKBS-11 x Azad Ganga with a heterotic range of 20.28 to -24.46 . Parbhani Kranti $x$ Red Bhindi, Parbhani Kranti x Lam-1, Parbhani Kranti X Pusa Sawani, SKBS-11 x Red Bhindi and Red Bhindi x Pusa Sawani showed desirable heterosis for number of nodes with heterotic range of 17.26 to -7.29 respectively. The significant desirable heterosis was exhibited by cross combinations Azad Ganga x Parbhani Kranti, SKBS-11x Pant Bhindi, SKBS-11 x Azad Ganga, SKBS11 x Lam-1and Pant Bhindi x Arka Anamika for internodal distance with a heterotic range of -29.02 to $24.36 \%$. For pod length the cross combinations showing significant desirable heterosis were SKBS-11 X Lam-1, SKBS-11 x Azad Ganga, SKBS-11 x Pusa Sawani,
SKBS-11 x Pant Bhindi and Pant Bhindi $\mathrm{x}$ Red Bhindi with a heterotic range of -23.65 to $32.32 \%$. The significant desirable heterosis for pod girth were exhibited by cross combinations SKBS-11 x Pant Bhindi, SKBS11 x IC-117018, Pant Bhindi x Pusa Sawani,IC-117018 x Pusa Sawani and Azad Ganga x Pusa Sawani respectively with a heterotic range of 30.42 to $35.22 \%$. For average pod weight, the heterosis ranged from 33.69 to $-9.38 \%$, was exhibited by cross combinations SKBS-11 x IC-117018, SKBS11 x Parbhani Kranti, Pant Bhindi x Azad Ganga, SKBS-11 x Pant Bhindi and Pant Bhindi x Parbhani Kranti respectively. For number of pods plant ${ }^{-1}$, Pant Bhindi $x$ Pusa Sawani, Red Bhindi x Pusa Sawani, Parbhani Kranti x Lam-1, Parbhani Kranti x Red Bhindi and SKBS-11 x Red Bhindi showed desirable heterotic range of 30.41 to $-4.71 \%$ respectively. Majority of cross combinations Viz; IC-117018 x Pusa Sawani, SKBS-11 xIC-117018, SKBS-11 x Parbhani Kranti, Pant Bhindi x Pusa Sawani and Pant Bhindi x Azad Ganga showed positive heterosis for pod yield plant ${ }^{-1}$. The extent of heterosis exhibited a range of 57.13 to $-0.43 \%$. For number of seeds pod $^{-1}$ the cross combinations showing desirable significant heterosis are Parbhani Kranti x Pusa Sawani, Lam-1 x GO-2, SKBS11 x Pusa Sawani, GO-2 x Pusa Sawani and SKBS-11 X IC-117018, respectively with heterotic range of 42.91 to $-24.90 \%$. The significant desirable heterosis was exhibited by cross combinations SKBS-11 x GO-2, SKBS-11 x Parbhani Kranti, SKBS-11 x Red Bhindi, SKBS-11 x Pant Bhindi and Pant Bhindi $x$ Red Bhindi respectively for 100 seed weight, with heterotic range of 17.38 to $5.10 \%$. For seed yield plant ${ }^{-1}$, Parbhani Kranti $\mathrm{x}$ Pusa Sawani, SKBS-11 x Pusa Sawani, SKBS-11 x Azad Ganga, Parbhani Kranti x arka Anamika, SKBS-11x Arka Anamika and SKBS-11 x Red Bhindi exhibited desirable significant heterotic range of 69.29 to $-43.18 \%$ respectively. 
Table.1 Estimation of heterosis (\%) over better parent for maturity and yield attributing traits in Okra (Abelmoschus esculentus L. Moench) (on pooled data)

\begin{tabular}{|c|c|c|c|c|c|c|c|}
\hline Crosses & $\begin{array}{l}\text { Days to } \\
\text { first } \\
\text { flowering }\end{array}$ & $\begin{array}{l}\text { Days to first } \\
\text { fruit picking }\end{array}$ & $\begin{array}{l}\text { Plant } \\
\text { height }\end{array}$ & $\begin{array}{l}\text { Number } \\
\text { of nodes }\end{array}$ & $\begin{array}{l}\text { Internodal } \\
\text { distance }\end{array}$ & Pod length & Pod girth \\
\hline SKBS-11 X Pant Bhindi & $-5.65 * *$ & $-5.43 * *$ & $-19.40 * *$ & $8.12 * *$ & $-27.89 * *$ & $-22.81 * *$ & $-30.42 * *$ \\
\hline SKBS -11 x IC 117018 & $4.75 * *$ & $2.76^{*}$ & $-15.69 * *$ & $8.51 * *$ & $-22.79 * *$ & $-21.04 * *$ & $-21.77 * *$ \\
\hline SKBS -11 x Azad Ganga & $3.95^{*}$ & $3.65^{* *}$ & $10.93 * *$ & $7.84 * *$ & $-24.81 * *$ & $-23.50 * *$ & 1.35 \\
\hline SKBS -11 x P. Kranti & $-4.99 * *$ & $-6.90 * *$ & $-14.85 * *$ & 2.31 & $-22.48 * *$ & $-18.30 * *$ & 4.34 \\
\hline SKBS -11 x Lam I & $-10.79 * *$ & $-9.61 * *$ & $-19.25 * *$ & $7.53 * *$ & $-23.48 * *$ & $-23.65 * *$ & $-9.60 *$ \\
\hline SKBS -11 x G0-2 & $-11.33 * *$ & $-8.52 * *$ & $-14.33 * *$ & $6.87 *$ & $-21.29 * *$ & $-20.61 * *$ & $-14.26 * *$ \\
\hline SKBS -11 x Red Bhindi & $-5.36 *$ & $-6.77 * *$ & $-12.18 * *$ & $11.28 * *$ & $-20.24 * *$ & $-13.45 * *$ & $-13.21 * *$ \\
\hline SKBS -11 x A. Anamika & $-11.24 * *$ & $-12.07 * *$ & $16.45^{* *}$ & 5.20 & $-2.78 * *$ & $-19.07 * *$ & -5.87 \\
\hline SKBS -11 x Pusa Sawani & -0.43 & -1.30 & $20.28 * *$ & -1.36 & $-21.70 * *$ & $-23.20 * *$ & -3.75 \\
\hline Pant Bhindi x IC 117018 & 1.09 & $3.40 *$ & $-19.39 * *$ & -4.54 & $-22.57 * *$ & $-10.40 * *$ & $-14.41 * *$ \\
\hline Pant Bhindi x Azad Ganga & 1.80 & 1.58 & -4.20 & $-7.29 *$ & $11.20 * *$ & $-10.10 * *$ & $20.99 * *$ \\
\hline $\begin{array}{l}\text { Pant Bhindi x Parbhani } \\
\text { Kranti }\end{array}$ & $-5.33 * *$ & $-6.38 * *$ & $-13.58 * *$ & -0.25 & $14.37 * *$ & $8.42 * *$ & $16.93 * *$ \\
\hline Pant Bhindi x Lam I & 0.01 & $3.20 *$ & -1.89 & -3.12 & $3.17 *$ & 2.30 & $35.22 * *$ \\
\hline Pant Bhindi x G0-2 & $-7.17 * *$ & $-10.40 * *$ & $-15.19 * *$ & -1.44 & $12.23^{* *}$ & $-15.43 * *$ & $21.15^{* *}$ \\
\hline Pant Bhindi x Red Bhindi & $-3.98^{*}$ & $-5.71 * *$ & $-16.10 * *$ & $7.71 *$ & $-22.79 * *$ & $-12.31 * *$ & $22.15^{* *}$ \\
\hline Pant Bhindi x Arka Anamika & $-7.85 * *$ & $-8.05 * *$ & $6.58 * *$ & $5.98 *$ & $-23.39 * *$ & $-21.92 * *$ & $28.56 * *$ \\
\hline Pant Bhindi x Pusa Sawani & 1.29 & $1.35 * *$ & 2.17 & $-3.67 * *$ & $24.36 * *$ & $32.32 * *$ & $-20.32 * *$ \\
\hline IC 117018 x Azad Ganga & $-4.58 * *$ & $-3.54 * *$ & $6.90 * *$ & -2.28 & $14.43 * *$ & $-15.77 * *$ & $-9.60 *$ \\
\hline IC 117018 x P. Kranti & 0.08 & 1.98 & $-20.17 * *$ & $6.78^{*}$ & $-9.94 * *$ & $-17.76 * *$ & 0.65 \\
\hline I C 117018 x Lam1 & $4.34 * *$ & $4.07 * *$ & $-9.66 * *$ & $6.14 *$ & $-6.65 * *$ & $-16.01 * *$ & $1.08 * *$ \\
\hline IC117018 x G0-2 & 1.59 & $3.28 *$ & $7.18 * *$ & 1.16 & $-11.11 * *$ & $9.08 * *$ & $14.98 * *$ \\
\hline
\end{tabular}




\begin{tabular}{|c|c|c|c|c|c|c|c|}
\hline IC 117018 x Red Bhindi & $-5.50 * *$ & $-5.65 * *$ & $-10.11 * *$ & $-5.93 * *$ & $-11.51 * *$ & -5.78 & $-17.03 * *$ \\
\hline IC 117018 x Arka Anamika & $-4.65 * *$ & $-12.80 * *$ & $-7.64 * *$ & $6.16^{*}$ & $-11.63 * *$ & $-13.85 * *$ & $-14.23 * *$ \\
\hline IC 117018 x Pusa Sawani & $-4.75 * *$ & $-4.13 * *$ & $-7.02 * *$ & $7.42 *$ & $7.60 * *$ & $-20.96 * *$ & $-19.78 * *$ \\
\hline Azad Ganga x P. Kranti & $3.04 *$ & 1.87 & $-24.46 * *$ & 4.95 & $-29.02 * *$ & $-16.24 * *$ & -5.09 \\
\hline Azad Ganga x Lam I & $-9.27 * *$ & $-7.81 * *$ & $-14.30 * *$ & $-4.24 * *$ & $-16.18 * *$ & $11.70 * *$ & $-13.60 * *$ \\
\hline Azad Ganga x GO-2 & $3.52 *$ & $3.62 * *$ & $10.19 * *$ & $10.84 * *$ & $20.39 * *$ & $-18.49 * *$ & -6.80 \\
\hline Azad Ganga x Red Bhindi & 1.41 & $2.52 *$ & $-8.96 * *$ & 9.59 & $-18.15 * *$ & $-10.27 * *$ & $17.58 * *$ \\
\hline Azad Ganga x A. Anamika & $2.60 *$ & 2.30 & $6.83 * *$ & 0.85 & $-19.85 * *$ & $9.70 * *$ & $-15.11 * *$ \\
\hline Azad Ganga x Pusa Sawani & $-9.26 * *$ & $-8.99 * *$ & $7.19 * *$ & $8.84 * *$ & $14.73 * *$ & $12.25 * *$ & $-19.21 * *$ \\
\hline Parbhani Kranti x Lam I & 1.03 & 0.67 & -0.78 & $16.28 * *$ & $-13.00 * *$ & -3.51 & $8.47 *$ \\
\hline Parbhani Kranti x GO-2 & $-4.46 * *$ & $-6.08 * *$ & $-13.32 * *$ & $9.70 * *$ & $-19.99 * *$ & $9.98 * *$ & 1.81 \\
\hline $\begin{array}{l}\text { Parbhani Kranti } x \quad \text { Red } \\
\text { Bhindi }\end{array}$ & $-10.58 * *$ & $-9.85 * *$ & -3.62 & $17.26 * *$ & $-16.62 * *$ & $-10.67 * *$ & $14.10 * *$ \\
\hline $\begin{array}{llll}\text { Parbhani } & \text { Kranti } & \text { x } & \text { A. } \\
\text { Anamika } & & & \end{array}$ & $2.81 *$ & $2.43 *$ & $11.57 * *$ & 2.50 & $-11.15 * *$ & $11.45 * *$ & $-15.48 * *$ \\
\hline Parbhani Kranti x P. Sawani & $-6.01 * *$ & $-5.59 * *$ & $9.07 * *$ & $15.85 * *$ & 1.25 & $12.70 * *$ & $-15.90 * *$ \\
\hline Lam I $x \quad$ GO-2 & $-7.72 * *$ & $-5.05 * *$ & $-13.76 * *$ & $-7.23 *$ & $-16.67 * *$ & $9.83 *$ & 7.88 \\
\hline Lam I x Red Bhindi & 0.84 & 1.66 & -3.34 & -5.31 & $7.46 * *$ & 0.94 & $10.56 * *$ \\
\hline Lam I x Arka Anamika & 2.13 & 1.06 & $-9.21 * *$ & -1.83 & $-14.76 * *$ & $7.67 *$ & $11.86 * *$ \\
\hline Lam 1 x Pusa Sawani & $-3.83 *$ & $-3.44 * *$ & -0.58 & -3.25 & -2.92 & $18.00 * *$ & $-16.22 * *$ \\
\hline GO-2 x Red Bhindi & $4.62 * *$ & 0.39 & $-16.29 * *$ & -1.24 & $11.42 * *$ & $-8.66 * *$ & $17.75 * *$ \\
\hline GO-2 $x$ Arka Anamika & $8.82 * *$ & $5.53 * *$ & $14.74 * *$ & -4.95 & $-21.12 * *$ & $10.45 * *$ & -0.07 \\
\hline GO-2 x Pusa Sawani & $5.92 * *$ & $3.27 *$ & $10.13 * *$ & 4.76 & $-13.42 * *$ & $21.18 * *$ & -3.49 \\
\hline Red Bhindi x Arka Anamika & $-7.50 * *$ & $-9.87 * *$ & $-7.66 * *$ & 2.10 & $-14.92 * *$ & $12.23 * *$ & $1.21 * *$ \\
\hline Red Bhindi x Pusa Sawani & $-3.51 * *$ & $-3.64 * *$ & $10.84 * *$ & $19.45 * *$ & $-6.06 * *$ & $18.63 * *$ & $-2.01 * *$ \\
\hline Arka Anamika x P.Sawani & $-9.57 * *$ & $-6.78 * *$ & $8.26 * *$ & -2.61 & $-6.99 * *$ & $26.03 * *$ & -6.16 \\
\hline
\end{tabular}


Table.2 Estimation of heterosis (\%) over better parent for maturity and yield attributing traits in Okra (Abelmoschus esculentus L. Moench) (on pooled data)

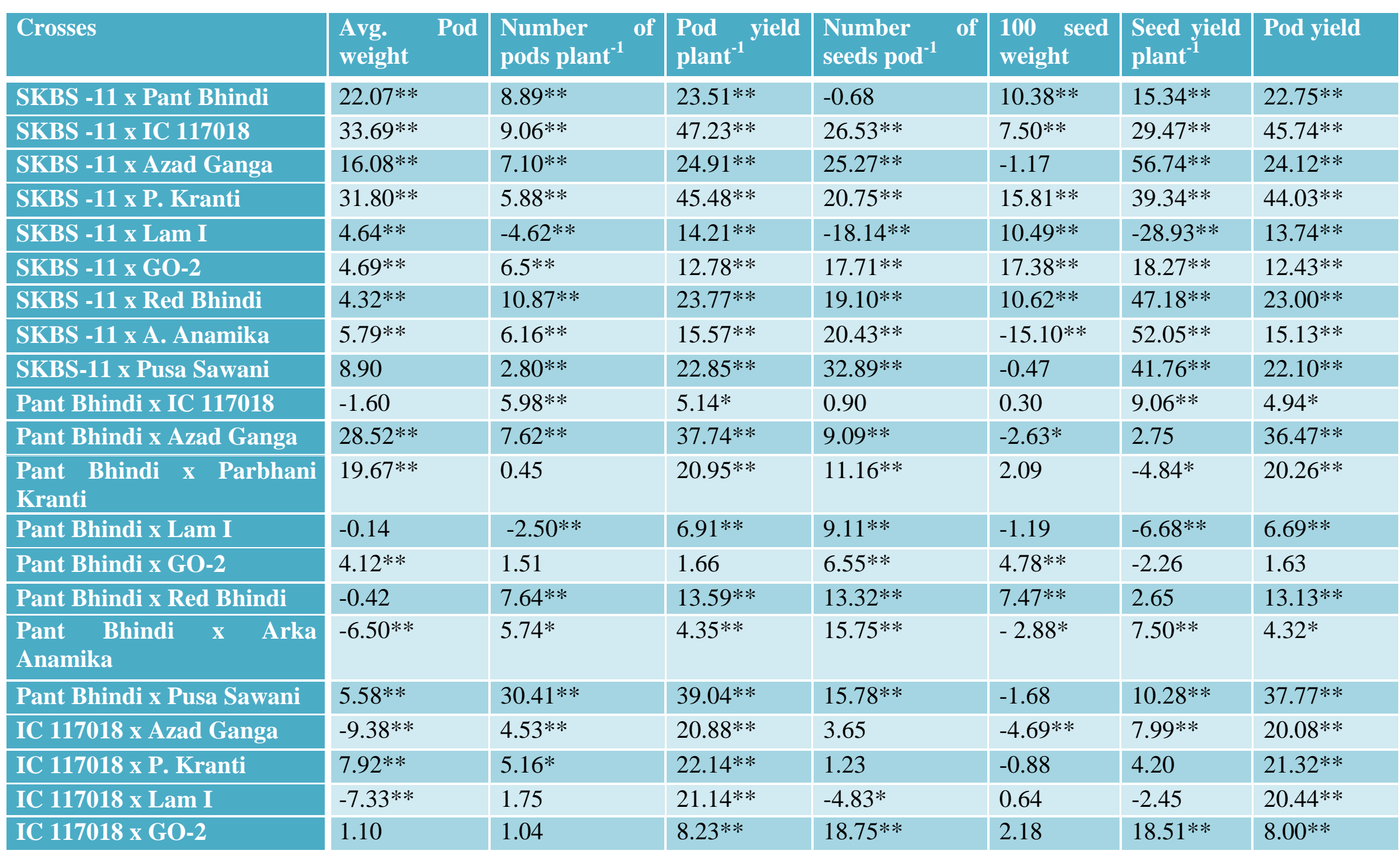




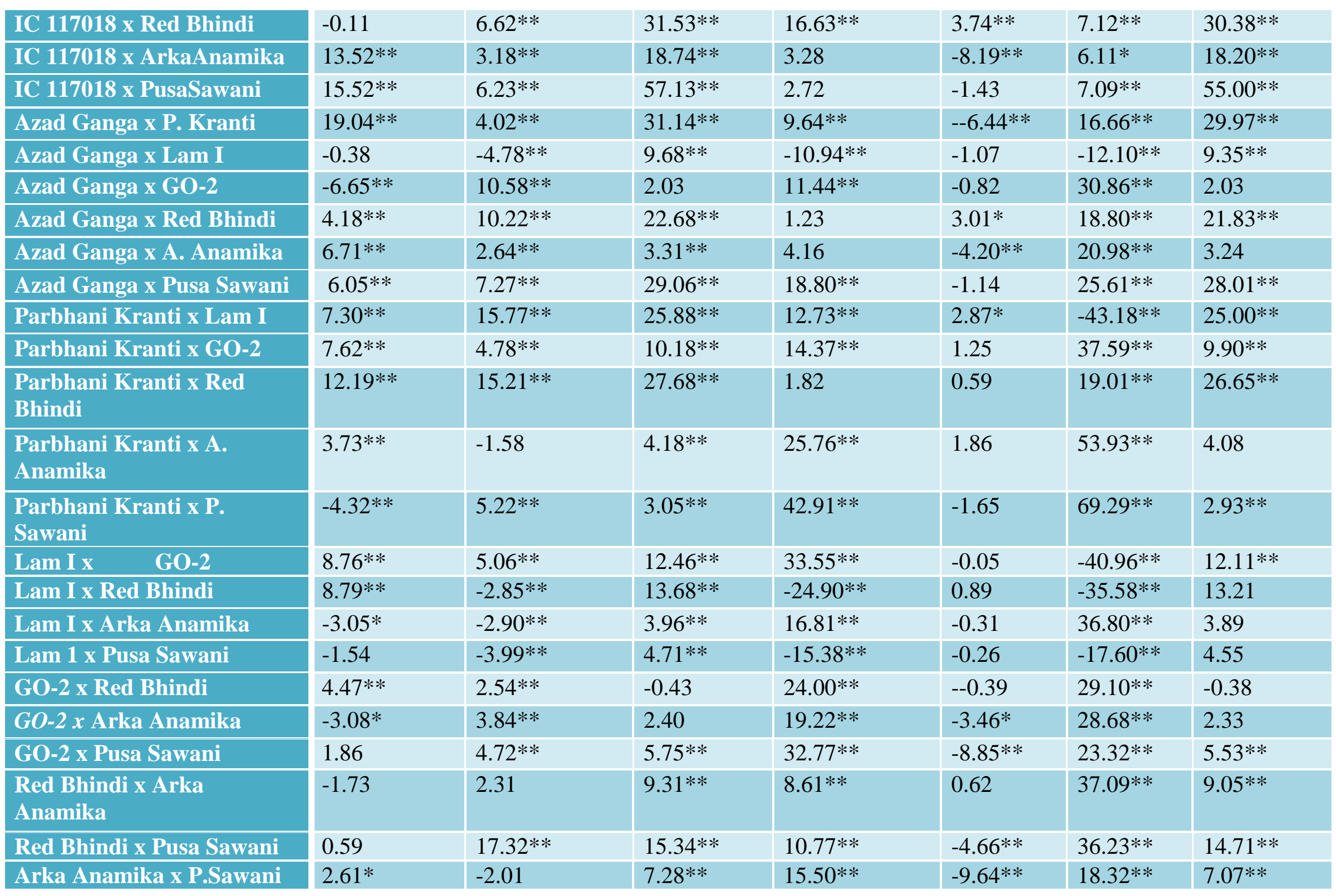


For pod yield, significant desirable heterossis was exhibited by cross combinattions IC117018 x Pusa Sawani, SKBS-11 x IC-117018, SKBS-11 x Parbhani Kranti and Pant Bhindi $x$ Azad Ganga respectively, with a heterotic range of 55.00 to $-0.38 \%$. Significant and desirable heterosis of variable magnitude for maturity and yield traits has been reported by several workers. Jindal et al., (2010) reported heterosis for days to first flowering, plant height and internodal distance (Table 2).

Khanokar and Katharia (2010) observed heterobeltoisis in desirable direction for pod length, pod weight, number of pods, average pod weight and pod yield. Similarly Wammanda et al., (2010) reported heterobeltoisis for number of pods plant ${ }^{-1}$, plant height and pod length.

Likewise, Thirupati et al., (2012) observed heterosis in okra for pod yield, days to first flowering and total yield. Ali et al., (2013) reported that heterosis in the desirable direction was due to various yield attributing traits of okra except number of branches plant ${ }^{-1}$.

Thirupati et al., (2013) reported standard heterosis for total pod yield and number of pods plant $^{-1}$ and negative heterosis for days to first flowering and intermodal length.

In the present study different cross combinations showed desirable significant heterosis for different characters. No cross combination showed desirable heterosis in all characters. The cross combinations showing desirable heterosis in majority of the characters were SKBS-11 x Arka Anamika, for days to first flowering and days to first pod picking, SKBS-11 x Pusa Sawani for plant height and pod length, Parbhani Kranti x Pusa Sawani for number of nodes, SKBS-11 x Parbhani Kranti for average pod weight and pod yield and Pant Bhindi x Pusa Sawani for number of pods.

\section{References}

Ali H.A., Obedella M.H.Z. and Helaly A.A. 2013. Combining ability and heterosis studies for yield and its components in Okra. American-Eurasian journal Agric. \& Environ. Sciences. 13(2):162-167

Jindal S.K., Deepak Arora and Ghai T.R. 2010. Studies on heterosis for earliness in spring season okra. SABRAQ-Journal of Breeding and Genetics. 42(2):65-73.

Khanokar, S.M., Kathira. K.B. 2010. Hetrobeltoisis, inbreeding depression and heritability studies in Okra. Electronic Journal of Plant Breeding. 1(4): 731-741.

Singh B; srivastava, D.K; yadav, J.R. and Singh, P. 2001. Combining ability studies in okra. Progressive Agriculture. 1; 1, 2933.

Thirupati M Reddy., Kadiyala HariBabu., Mutyala Ganesh 2013. Exploitation Of hybrid vigour for yield and its components in Okra. American Journal of Agricultural sciences and Technology. $1: 1-17$

Thirupati Reddy, Haribabukadiyala, Ganesh Mutyala, Hameedunisa. 2012. Heterosis for yield and yield components in Okra. Chilean Journal of Agricultural Research. 72(3):316-326.

Wammanda. D.T., Kadam. A.M., Jonah. P.M. 2010. Combining ability analysis and heterosis in a diallel cross of Okra. African Journal of Research.5 (16):21082115.

\section{How to cite this article:}

Makdoomi, M.I., Kouser P. Wani, Z.A. Dar, K. Hussain, Ambreen Nabi, Faheema Mushtaq and Shahnaz Mufti. 2018. Heterosis Studies in Okra (Abelmoschus esculentus L. Moench). Int.J.Curr.Microbiol.App.Sci. 7(02): 3297-3304. doi: https://doi.org/10.20546/ijcmas.2018.702.396 